\title{
Adsorptive removal of lead and arsenic from aqueous solution using soya bean as a novel biosorbent: equilibrium isotherm and thermal stability studies
}

\author{
Nisha Gaur ${ }^{1} \cdot$ Aayush Kukreja $^{1} \cdot$ Mahavir Yadav $^{1} \cdot$ Archana Tiwari $^{1}$
}

Received: 12 May 2017 / Accepted: 11 June 2018 / Published online: 18 June 2018

(c) The Author(s) 2018

\begin{abstract}
In this study, adsorption potential of soya bean adsorbent for lead $(\mathrm{Pb})$ and arsenic (As) has been assessed in order to consider its suitability for purification of wastewater containing heavy metals. The main focus of study was on $\mathrm{Pb}$ and As. Batch experiments were performed to study the adsorption of $\mathrm{Pb}$ and $\mathrm{As}$ on soya bean absorbent. The effect of various experimental parameters (adsorbent dose, contact time, temperature and $\mathrm{pH}$ ) was studied, and optimal conditions were determined. The effect of adsorbent dose on the biosorption of $\mathrm{Pb}$ and $\mathrm{As}$ from aqueous solution was studied at $37^{\circ} \mathrm{C}$ by varying the adsorbent amount from $1 \mathrm{~g} / 100 \mathrm{ml}$ to $4 \mathrm{~g} / 100 \mathrm{ml}$. Highest amount of $\mathrm{Pb}$ and As was adsorbed at sorbent amount of $3 \mathrm{~g} / 100 \mathrm{ml}$. The optimum $\mathrm{pH}$ for removal of $\mathrm{As}$ and $\mathrm{Pb}$ was found to be 2.0 and 4.0 0.26 . Maximum biosorption of $\mathrm{Pb}$ and $\mathrm{As}$ was achieved at $37^{\circ} \mathrm{C}$. The maximum percentage removal of $\mathrm{Pb}$ and As was attained at $60 \mathrm{~min}$ of shaking time. Langmuir and Freundlich isotherm models were utilized for equilibrium studies. It was found that biosorption by soya bean adsorbent was exothermic in nature. The thermal degradation analysis suggested that the degradation occurs in two steps and adsorbent is thermally stable.
\end{abstract}

Keywords Biosorption · Soya bean adsorbent $\cdot$ Lead and arsenic $\cdot$ Sorption isotherm and thermal analysis of biosorbent

\section{Introduction}

Pollution refers to the presence of undesirable substances, also known as pollutants, in the environment beyond the permissible limit which can harmfully affect every sphere of life. Sources of pollution can be natural as well as anthropogenic. Natural sources include geothermal activities, comets, space dust and volcanic activities, whereas anthropogenic sources have aroused mainly on account of rapid industrialization and massive use of chemical substances such as hydrocarbons, pesticides, chlorinated hydrocarbons and heavy metals (Marcano et al. 2003). The later-mentioned source is the major contributor to the pollution in contrast to the former one (Dubus et al. 2000). Out of large number of aforementioned anthropogenic sources, toxicological

Nisha Gaur

gaurnisha2007@gmail.com

1 School of Biotechnology, Rajiv Gandhi Proudyogiki Vishwavidyalaya, Airport Road, Bhopal, Madhya Pradesh 462033, India manifestations caused by heavy metals are well known and are considered as highly detrimental (Su 2014).

Metals having high atomic weight and a density of more than $5 \mathrm{~g} / \mathrm{cm}^{3}$ are regarded as heavy metals or transition metals. More than 20 different kinds of heavy metals are found in nature, but only a few of them are of great concern to human health. According to Agency for Toxic Substances and Disease Registry (ASTDR), Pb, cadmium, As and mercury are well known for showing its toxicity profile upon exposure (Jomova et al. 2010). Chiefly, human exposure to these metals occurs from industries and toxic waste sites. The non-biodegradable nature of these heavy metals further results in prolonged persistence in the environment. It is now known that existence of transition metals even at a very low concentration (Pico molar) in humans can result in fatal health effects (Jaishankar et al. 2014).

Lead $(\mathrm{Pb})$, cadmium $(\mathrm{Cd})$, arsenic (As) and mercury $(\mathrm{Hg})$ are the main pollutants that bring about heavy metal toxicity. The non-biodegradable nature of these metals is the chief reason that leads to their extended presence in the environment. Moreover, these metals can enter into the food chain and over a period of time gets accumulated in the human body. This accumulation can cause many health effects 
which might be irreversible in nature (Tamás et al. 2014; Tchounwou et al. 2012).

Ion exchange, chemical precipitation, reverse osmosis, land filling and bioslurries are the conventional treatment methods used for heavy metal remediation present in water and soil (Vinod and Sashidhar 2011). In addition, these methods have some major drawbacks of being expensive owing to the requirement of sophisticated infrastructure, generate toxic sludge which affects the environment and might not completely remove the metals (Singh and Gadi 2012).

Biosorption is a process which uses the biological materials for the removal of contaminants such as organic and inorganic or soluble and insoluble contaminants. In addition, this process has many advantages such as those metals $\left(\mathrm{K}^{+}, \mathrm{Mg}^{+}\right)$that are highly mobile and don't get accumulated with biomass during phytoremediation which can be easily removed through biosorption. Eradication of heavy metals along with dyes, phenolic compounds and pesticides is receiving lot of attention through this process (Fomina and Gadd 2014).

Biosorption capacity of citrus waste (orange, pomelo, grapefruit and lemon peel), banana (Musa paradisiaca), cassava, jackfruit, pomegranate, garlic peel for heavy metals ( $\mathrm{Pb}$, zinc, copper and chromium), anionic and basic dyes has been studied (Bhatnagar et al. 2015). In another investigation, litchi pericarps were used for the removal of As(III) from aqueous solution waste (Li et al. 2016). Suryan et al. reported the removal of $\mathrm{Pb}, \mathrm{Cd}, \mathrm{Ni}$ and $\mathrm{Cu}$ from aqueous solution using paper mill sludge. They found that the growing a sufficient quantity of bacterial, fungal and algal biomass is a costly method. Development of inexpensive biosorbent such as waste biomass from agriculture industry and paper industry represents a cost-effective method for metal removal (Suryan and Ahluwalia 2010). A recent investigation showed the removal of As by non-living biomass of marine macrophytes (Pennesi et al. 2012). In another study, a non-living lichen (Cladonia rangiformis) was used as a biosorbent for $\mathrm{Pb}$ removal from aqueous solution (Ekmekyapar et al. 2012). Researchers also reported that dead biomass of Mesorhizobium amorphaeto can also act as a robust biosorbent for $\mathrm{Cd}$ removal from aqueous waste (Mohamad et al. 2012). Goyal et al. found that the non-living biomass of Spirulina sp. showed the better biosorption capacity in zinc and $\mathrm{Pb}$ removal (Aneja et al. 2010). Guo et al. developed the transgenic Arabidopsis thaliana to increase the tolerance and accumulation of $\mathrm{Cd}$ and As by simultaneous over-expression of AsPCS1 and YCF1 genes (Guo et al. 2012). In another study Zhang and Liu showed the enhancement of resistance capability of transgenic Alfalfa toward the heavy metals and organic pollutants (Zhang and Liu 2011).

In this work soya bean waste was used as a novel adsorbent for removal of $\mathrm{Pb}$ and $\mathrm{As}$ from aqueous solution. As non-living biomass does not require any maintenance and nutrient supply and can be easily obtained from industrial waste which adds the ease of availability and makes the process economic; therefore, they have gained more preference over living biomass (Vijayaraghavan and Yun 2008). In addition, proper maintenance along with sustained environmental condition is required to maintain living biomass. As metals bind intracellularly, even by providing these conditions, recovery of heavy metals cannot be done efficiently from living biomass. Therefore, soya bean waste biomass can be used as an adsorbent due to its availability and its physicochemical characteristics (Modak and Natarajan 1995; Vijayaraghavan and Yun 2008).

The purpose of the present work was to examine the efficiency of soya bean adsorbent for the removal of heavy metals from aqueous solution. This material is chemically free and environmental friendly. The batch studies were employed: parameters such as adsorbent dose, contact time, temperature and $\mathrm{pH}$ were studied. Two different isotherm models were tested. Thermal degradation analysis was also studied to check the thermal stability of prepared soya bean adsorbent. The present study is an attempt to try a novel biosorbent which is simple, cost-effective and suitable for application in industries.

\section{Materials and methods}

\section{Adsorbent preparation and its characterization}

Soya bean seeds were collected from Annapurna Krishi Bhandar, Bhopal (Madhya Pradesh), India. It was sundried for about 2-5 days before being grounded into fine particles using manual grinding machine and with sifter to obtain $120 \mathrm{~mm}$ fine dust particles. The finer dust particles were treated with $0.5,1,1.5$ and $2 \%$ of $\mathrm{NaOH}$ solution including negative control and later reintroduced in an oven at $30{ }^{\circ} \mathrm{C}$ for $30 \mathrm{~min}$ and preserved in a sample container for future use.

\section{Adsorbent characterization}

The characterization of untreated and treated adsorbent was performed using Fourier transform infrared spectroscopy (FT-IR), scanning electron microscope (SEM) and Malvern Zetasizer Nano ZS. FT-IR analysis was performed for the presence of different functional groups and sites in the adsorbent. In this, okara was analyzed on diffuse reflectance spectroscopy (IRprestige-21, SHIMADZU) by mixing it in $\mathrm{KBr}(1: 100)$. SEM was carried out at Sophisticated Analytical Instrumentation Facility Laboratory, IIT, Mumbai, to check the surface area. Malvern Zetasizer Nano ZS was used to check the particle size of the adsorbent. Each analysis 
lasted for $70 \mathrm{~s}$ and was performed at $25^{\circ} \mathrm{C}$ in disposal sizing cuvette with an attenuator of 6.

\section{FT-IR}

FT-IR spectroscopic analysis was performed for the determination of functional groups present on the surface of adsorbent both before and after adsorption process (IRprestige-21, SHIMADZU, Japan). FT-IR spectra were recorded between 4000 and $650 \mathrm{~cm}^{-1}$. Potassium bromide $(\mathrm{KBr})$ pellet disks were prepared by mixing $1 \mathrm{mg}$ of dried sample with $500 \mathrm{mg}$ of $\mathrm{KBr}$ (Merck, spectroscopy grade) in an agate mortar and then pressing the resulting mixture at 10 tones $/ \mathrm{cm}^{2}$ for 15 min under vacuum.(Bello et al. 2015).

\section{Field emission gun scanning electron microscopes (FEG-SEM)}

To obtain the information about the surface morphologies of un-activated, activated and activated metals-loaded adsorbent, FEG-SEM was performed (JEOL JSM-7600F FEGSEM) at accelerating voltage of $5 \mathrm{kV}$ at different magnification 3000x. To enhance the electron conductivity of the samples, coating was done using gold particles. FEG-SEM analysis was done at SAIF IIT, Mumbai (Bekçi et al. 2007).

\section{Zetasizer}

The particle size and Polydispersity Index of adsorbent before accumulation of metal were determined using zetasizer (Zetasizer-ZEN 2600 Malvern instrument, Ltd., UK) equipped with Malvern PCS software at Sophisticated Analytical Instrumental Laboratory (SAIL), RGPV Bhopal, India (Kharia and Singhai 2013).

\section{Thermo-gravimetric analysis (TGA)}

Thermo-gravimetric analysis (TGA) was used for the characterization of thermal degradation of adsorbent before and after metal accumulation. In addition, it is used to measure the material thermal stability and the rate of change of weight of a sample as a function of time and temperature in a controlled atmosphere. It is primarily used to determine the thermal and/or oxidative stability of materials as well as their compositional properties. The weight of a sample is recorded as a function of temperature under air or inert atmosphere, such as helium or argon. To slow down the oxidation, the measurement is performed under lean oxygen atmosphere $\left(1-5 \% \mathrm{O}_{2}\right.$ in $\mathrm{N}_{2}$ or $\left.\mathrm{He}\right)$.

The thermal degradation was carried out at Sophisticated Analytical Instrumentation Facility Laboratory, IIT, Mumbai, using TGA analyzer from PerkinElmer (Pyris Diamond). The ion source was operated at $70 \mathrm{eV}$, and nearly $5 \mathrm{mg}$ samples were used to prevent heat and mass transfer limitations. Samples were heated at $25-1000{ }^{\circ} \mathrm{C}$ for $30 \mathrm{~min}$, and the experiments were performed under argon flow $(1 \mathrm{l} / \mathrm{h})$ with slowly increasing the temperature at the rate of $10{ }^{\circ} \mathrm{C} / \mathrm{min}$ (Carrier et al. 2011).

\section{Batch adsorption study}

It was carried out at room temperature in laboratory by using industrial wastewater collected from Govindpura Industrial Area, Bhopal (India). The physicochemical properties of wastewater are mentioned in Table 1. The different factors affecting adsorption process of the metal ions under study $\left(\mathrm{Pb}^{2+}\right.$ and $\left.\mathrm{As}\right)$ such as adsorbent dose, contact time, temperature and $\mathrm{pH}$ have been studied using wastewater. A series of 250-ml Erlenmeyer flask with $1 \mathrm{~g}$ of biosorbent were taken and $100 \mathrm{ml}$ of wastewater containing initial concentration of lead and arsenic 1.24 and $0.24 \mathrm{mg} / \mathrm{ml}$ was added into the flasks. The adsorption mixture was agitated for a time period of 120 min using horizontal orbital shaker at a temperature range of $37^{\circ} \mathrm{C}$ at $100 \mathrm{rpm}$. The optimum uptake of $\mathrm{Pb}$ and As was determined by their uptake from aqueous solution at different time interval of 20-120 min. The effect of physical parameters on the $\mathrm{Pb}$ and As sorption was evaluated at a $\mathrm{pH}$ range of $2-12$, temperature range $28-40^{\circ} \mathrm{C}$ and adsorbent dose range 1-4 g/100 ml. In each set of experiment, the effect of one factor was evaluated by varying one factor at a time while keeping all other factors constant. The amount of $\mathrm{Pb}$ and $\mathrm{As}$ accumulation by adsorbent was analyzed by AAS, and the specific metal uptake $(q)$ by biomass and biosorption efficiency $(R \%)$ was calculated by Eqs. (1) and (2), respectively.

$q=\frac{V \times\left(C_{i}-C_{e}\right)}{1000 \times W}$

$R=\frac{\left(C_{i}-C_{e}\right)}{\left(C_{i}\right)} \times 100 \%$

where $V$ is the volume of solution, $W$ is the amount of adsorbent, and $C_{i}$ and $C_{e}$ are the initial and final concentration of the solution after adsorption in $\mathrm{mg} / 1$.

Table 1 Physicochemical properties of industrial wastewater

\begin{tabular}{lc}
\hline Parameters & \multicolumn{1}{l}{ Values } \\
\hline $\mathrm{pH}$ & $5.8 \pm 0.11$ \\
Temperature $\left({ }^{\circ} \mathrm{C}\right)$ & $14 \pm 0.01$ \\
Lead $(\mathrm{mg} / \mathrm{ml})$ & $1.24 \pm 0.004$ \\
Arsenic $(\mathrm{mg} / \mathrm{ml})$ & $0.24 \pm 0.007$ \\
TDS $(\mathrm{mg} / \mathrm{ml})$ & $0.983 \pm 1.2$ \\
TSS $(\mathrm{mg} / \mathrm{ml})$ & $0.342 \pm 1.9$ \\
\hline
\end{tabular}




\section{Adsorption isotherm}

In the present study, Langmuir and Freundlich models were used to provide the equilibrium data.

\section{Langmuir isotherm}

Langmuir isotherm model is based on the assumption that binding sites present over adsorbent surface are generally homogeneously distributed. In addition, these binding sites bind to the single molecular layer with the same affinity. According to this model, there is no interaction between the molecules adsorbed over the adsorbent surface.

In Langmuir adsorption the uptake occurs on homogenous surface by monolayer sorption without interaction between adsorbed ions. Equation (3) represents the linear form of Langmuir isotherm,

$\frac{C_{e}}{q_{e}}=\frac{1}{q_{\max } b}+\frac{1}{q_{\max }} C_{e}$

where $q_{\max }$ is the maximum $\mathrm{Pb}$ and As ions uptake capacity per unit mass of adsorbent $(\mathrm{mg} / \mathrm{g})$ and $b$ is Langmuir constant $(1 / \mathrm{mol})$ related to energy of biosorption. Therefore, a plot of $C_{e} / q_{e}$ versus $C_{e}$ gives a straight line having slope $1 / q_{\max }$ and intercept $1 /\left(q_{\max } b\right)$ (Dabrowski 2001).

\section{Freundlich isotherm}

Freundlich isotherm studies the heterogeneous surface energies and gives the exponential distribution of active sites. The linear form of Freundlich isotherm equation is represented by

$\ln q_{e}=\ln K_{\mathrm{f}}+\frac{1}{n} C_{e}$

$K_{\mathrm{f}}$ and $n$ are Freundlich constants which indicate the adsorption capacity and adsorption intensity, respectively (Desta 2013).

\section{Statistical analysis}

Data are presented as mean \pm SEM. The experiments were performed in triplicate $(n=3)$. Comparison of data was carried out using two-way analysis of variance (ANOVA), and it was followed by Tukey's post hoc test to compare means. A $p$ value $<0.05$ was considered significant.

\section{Results and discussion}

\section{Characterization of adsorbent}

The heat as well as $1 \% \mathrm{NaOH}$ treatment was given to soya bean adsorbent for the activation of adsorbent. The treatments increase the porosity and surface area of the synthesized biosorbent as well as expose additional functional groups, which can improve the biosorption abilities (Jain and Gogate 2017). Figure 1 shows the effect of $\mathrm{NaOH}$ concentration on biosorption efficiency. The adsorption efficiency is directly proportional to the concentration of the activator up to $1 \%$ after that it became constant. The percentage of $\mathrm{Pb}$ and As biosorption with non-treated soya bean waste gave a value of 58.31 and $23.21 \%$, respectively. The addition of $1 \% \mathrm{NaOH}$ increased the adsorption ability of $\mathrm{Pb}$ and $\mathrm{As}$ to 70.42 and $37.10 \%$, respectively. FT-IR spectra, SEM and particle area analyzer were used to study the structural and morphological characteristics of adsorbent.

\section{FT-IR spectroscopy}

The FT-IR spectra of soya bean waste samples are shown in Fig. 2. It is an important technique to identify the characteristic functional groups, which are involved in adsorption of $\mathrm{Pb}$ and As. Figure 2a, b shows the FT-IR spectra of adsorbent before and after biosorption of $\mathrm{Pb}$ and As, respectively. A broad band between 3201.83 and $3518.16 \mathrm{~cm}^{-1}$ in both adsorbents is indicative of the presence of free and hydrogen bonded $\mathrm{OH}$ groups on adsorbent surface. This stretching is due to both the silanol groups $(\mathrm{Si}-\mathrm{OH})$ and adsorbed water (peak at $3400 \mathrm{~cm}^{-1}$ ) at the adsorbent surface (Abou-Mesalam 2003).

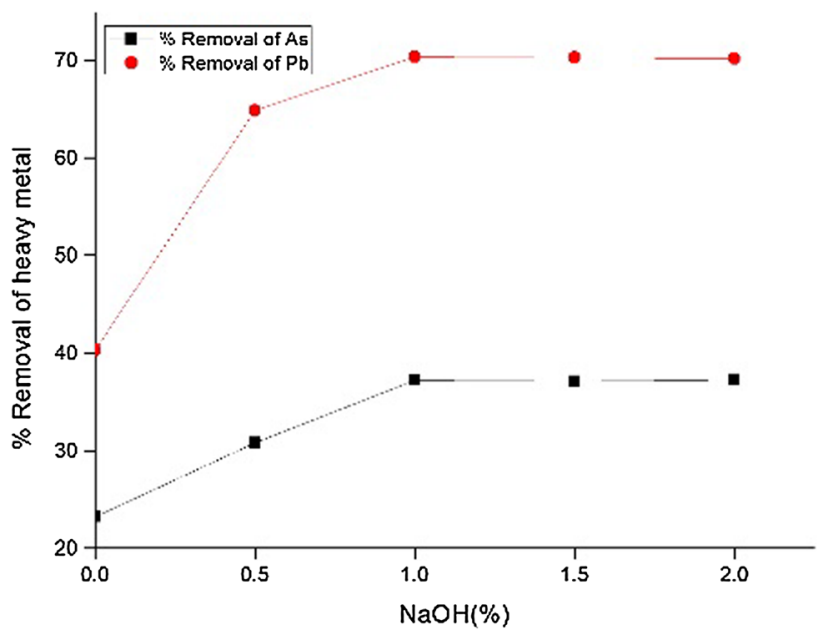

Fig. 1 Effect of $\mathrm{NaOH}$ concentration (\%) on $\mathrm{Pb}$ and As biosorption 

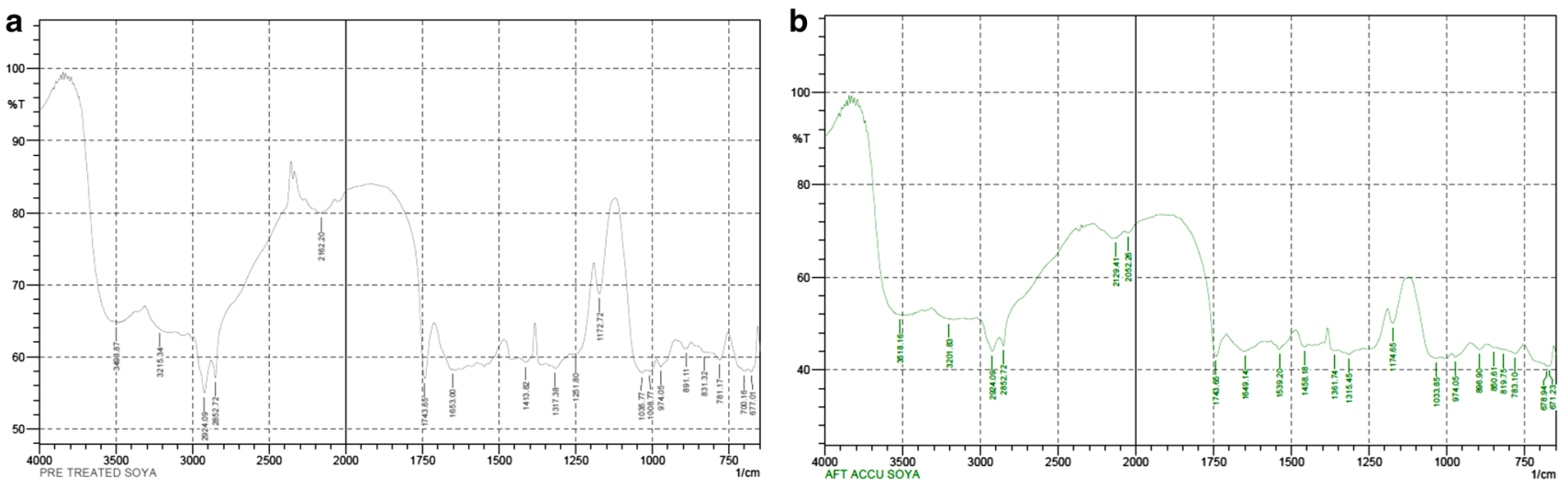

Fig. 2 FT-IR spectra of soya bean adsorbent before (a) and after (b) biosorption

The stretching of $\mathrm{OH}$ groups bound to methyl groups shows a signal between 2852.72 and $2924.09 \mathrm{~cm}^{-1}$. Similarly, peaks at 1743.65 and $1317.38 \mathrm{~cm}^{-1}$ are indicative of carboxyl group, while those at 1539.20 and $1458.18 \mathrm{~cm}^{-1}$ are indicative of $-\mathrm{CH}_{2}$ and $-\mathrm{CH}_{3}$ groups. The peak at $1251.80,1035.77,896.90$ and $850.61 \mathrm{~cm}^{-1}$ is due to $-\mathrm{SO}_{3}$ stretching, $\mathrm{C}-\mathrm{O}$ stretching, $\mathrm{C}=\mathrm{O}$ stretching and aromatic $-\mathrm{CH}$ stretching. The presence of polar groups on the surface of adsorbent is likely to give considerable cation exchange capacity to the adsorbents. The peaks at $783.10 \mathrm{~cm}^{-1}$ indicate the presence of $\mathrm{Si}-\mathrm{H}$ (Ho et al. 2001).

With the loading of metal ions, the shifting of the peaks is seen from about 3498.87, 3215.34, 1413.82, 1035.77, 891.11 and $781.17 \mathrm{~cm}^{-1}$. This clearly indicates that the functional groups at these wave numbers participate in the adsorption of metals on the surface. The shifting of peaks is present in both higher and lower wave numbers. The FT-IR spectra for $\mathrm{Pb}$ - and As-loaded okara show the shifting of peaks at $3518.16,3201.83,1539.20,1458.18,1033.85,896.90$ and $850.61 \mathrm{~cm}^{-1}$. These characteristics indicate that $-\mathrm{OH},-\mathrm{CH}_{2}$ and $-\mathrm{CH}_{3}$ groups, $-\mathrm{C}-\mathrm{O}$ groups of primary $\mathrm{OH}$ stretching and $-\mathrm{SO}_{3},-\mathrm{C}=\mathrm{O}$ groups are effective in adsorption of $\mathrm{Pb}$ and As onto okara. The above results are in line with previous findings (Srivastava et al. 2006).

\section{SEM}

The SEM micrograph of un-activated, activated and activated metals $(\mathrm{Pb}$ and $\mathrm{As})$-loaded adsorbents is shown in Fig. 3. As mentioned previously, the activated adsorbent contains exposed cavities and pores which favor the adsorption of metals. From Fig. 3c, it could be inferred that surface texture of the soya-based adsorbent changes drastically after the adsorption of the heavy metals. The surface of the soyabased biosorbent also appears uneven and irregular with cavities which facilitate interaction of heavy metals $(\mathrm{Pb}$ and As) with the biosorbent surface leading to proper metals adsorption. An alternation in rough surface (Fig. 3c) was examined after the use of $\mathrm{Pb}$ and As in the adsorption studies (Jain and Gogate 2017).

\section{Zetasizer analysis}

The instrument zetasizer uses the phenomenon of dynamic light scattering to reveal the particle size of the sample through the measurement of Polydispersity Index. The dynamic light scattering measurement shows polymer particles around $0.1 \mu \mathrm{m}$ with a polydispersity of 7 (Fig. 4).

Particles in suspension/solution undergo Brownian motion which is induced by the bombardment of the solvent particles that moves due to their thermal energy. When the laser light hits the particle surface, the smaller particles move faster as the rate of intensity of light is directly proportional to the size of particle. Also, the movement of the particle depends on the motion of solvent molecule.

\section{Thermal analysis of soya waste-based bioadsorbent}

The spent adsorbent causes various problems in its disposal and management. The current trend emphasizes on exploiting them for some beneficial purpose and rendering them harmless and non-threatening to the environment before they are being disposed off. The large amount of solid waste is produced during treatment of wastewater from low-cost adsorbents which has the great potential of energy recovery. However, the separation of the adsorbents from the solvents by sedimentation, filtration and centrifugation, dewatering and drying is very important. Moreover, TG analysis measures the change in weight loss of the adsorbent as a function of temperature and time. Heavy metals ( $\mathrm{Pb}$ and $\mathrm{As}$ )-loaded adsorbents and blank adsorbents are studied for their thermal degradation characteristics by thermo-gravimetric (TG) instrument.

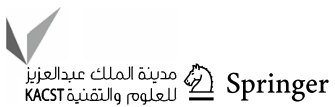



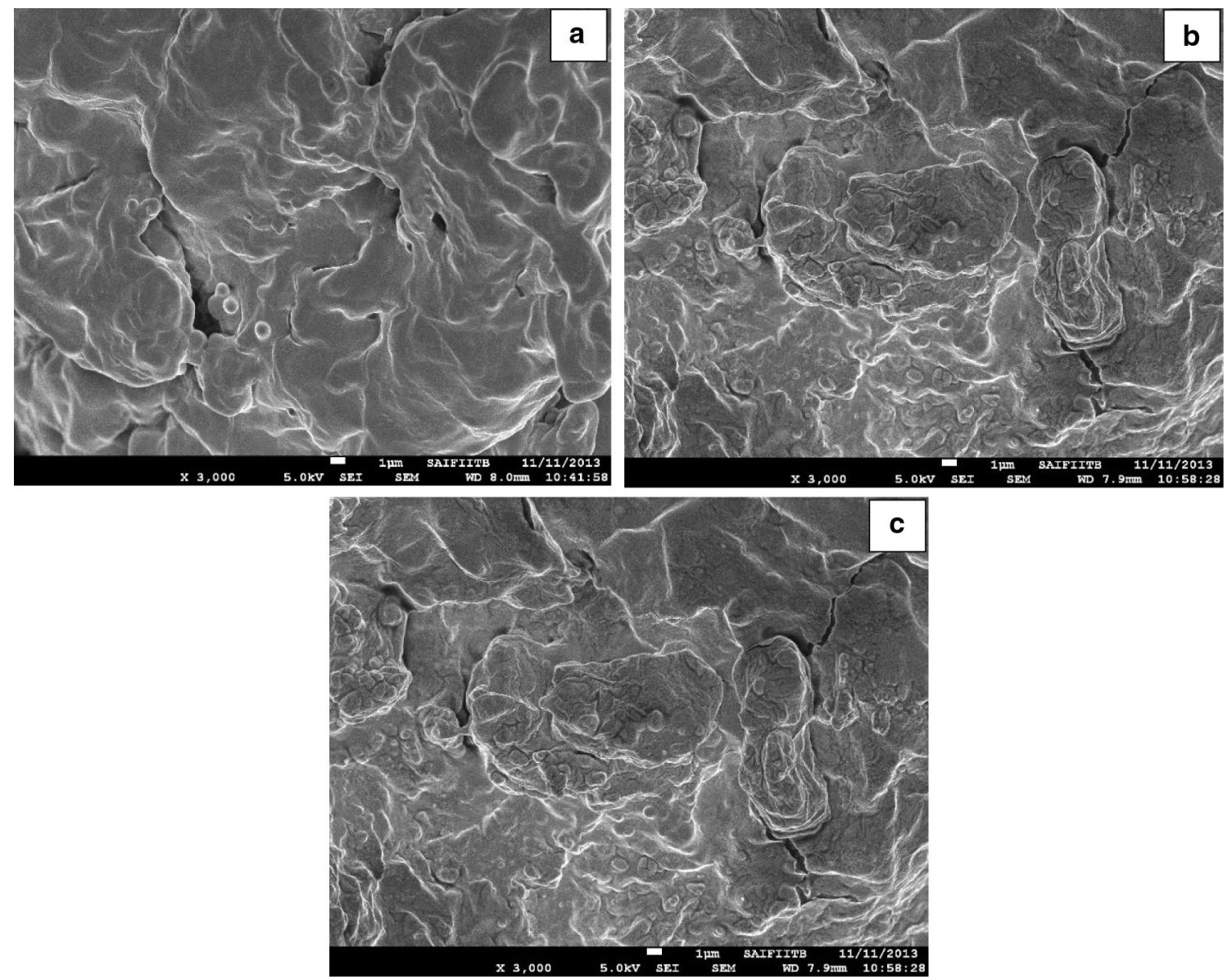

Fig. 3 SEM micrographs of a un-activated, $\mathbf{b}$ activated and $\mathbf{c}$ activated metals-loaded adsorbent at $3000 \times$

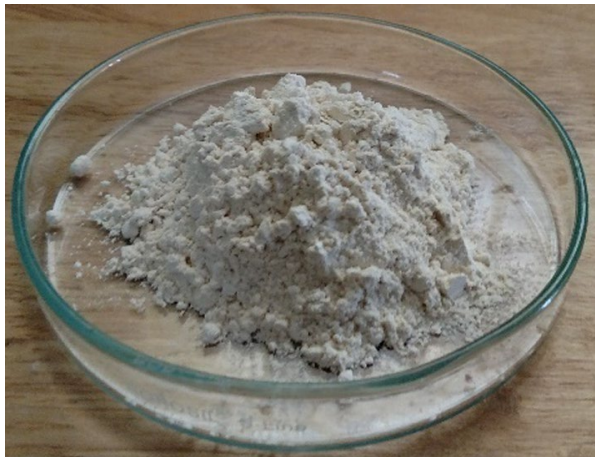

Fig. 4 Powdered adsorbent having particle size $0.1 \mu \mathrm{m}$

Thermal stability of soya waste-based bioadsorbent is directly dependent on decomposition temperature of its various oxides and functional groups. The surface groups present on carbons moiety and those formed as a result of interaction with oxidizing gases or solutions are generally quite stable even under vacuum at temperatures below $150{ }^{\circ} \mathrm{C}$, irrespective of the temperature at which they are formed. However, when the carbons are heated at higher temperatures, the surface groups decompose, producing $\mathrm{CO}\left(150-600{ }^{\circ} \mathrm{C}\right), \mathrm{CO}_{2}\left(350-1000{ }^{\circ} \mathrm{C}\right)$, water vapor and free hydrogen $\left(500-1000{ }^{\circ} \mathrm{C}\right)$. The principal experimental variables which could affect the thermal degradation characteristics in air and nitrogen flow in a TG experiment are the pressure, purge gas flow rate and the weight of sample. In the present study, the operating pressure was kept slightly positive; the purge gas flow rate was maintained at $200{ }^{\circ} \mathrm{C}$. The thermo-gravimetric analysis (TGA) curves of the native and $\mathrm{Pb}$ - and As-adsorbed soya waste are shown in Fig. 5a, b.

To investigate the mechanism of $\mathrm{Pb}$ and As adsorption as well as role of porosity, the nature of interaction between $\mathrm{Pb}$ and As and soya waste was explored by thermo-gravimetric (TG) analysis under nitrogen and air atmosphere at a heating rate of $10{ }^{\circ} \mathrm{C} / \mathrm{min}$. A peak in thermo-gravimetric curve in both the samples at temperature below $300{ }^{\circ} \mathrm{C}$ shows the removal of moisture and evolution of some lightweight molecule. The thermal degradation occurred in two steps in both the samples (before and after accumulation) as shown in Fig. 5a, b. The first degradation step in before accumulation started from 392.66 to $500{ }^{\circ} \mathrm{C}$ with a degradation peak at 

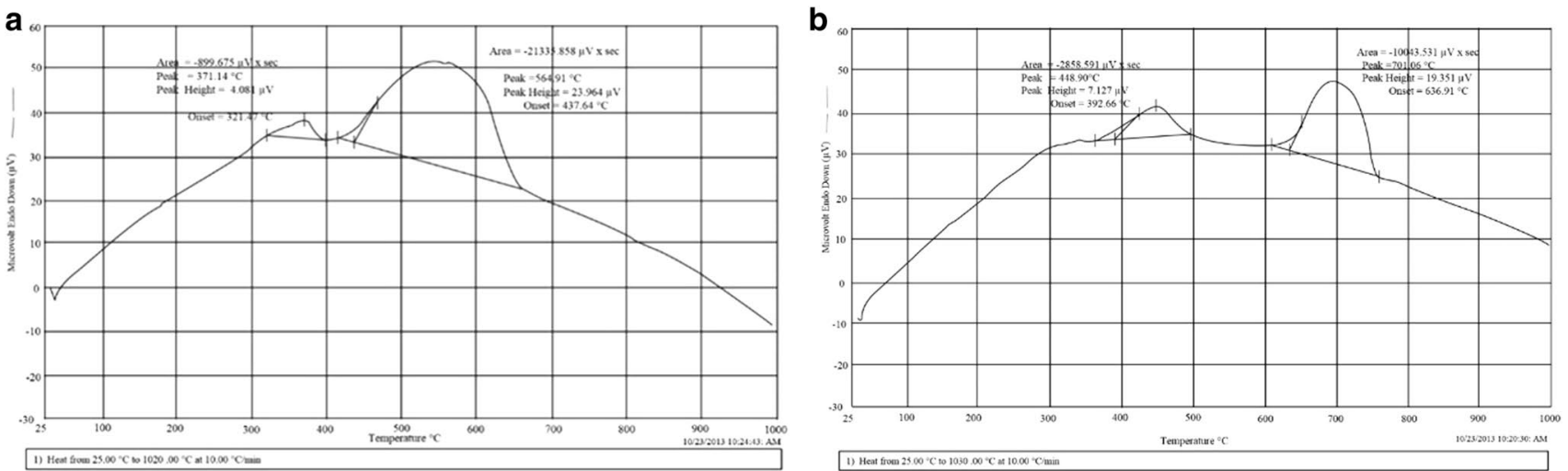

Fig. 5 TGA analysis of $\mathbf{a}$ before accumulation and $\mathbf{b}$ after accumulation of soya waste-based adsorbent in nitrogen atmosphere

$448.90{ }^{\circ} \mathrm{C}$, and the second degradation started from 636.91 to $750{ }^{\circ} \mathrm{C}$ with a degradation peak at $701.06{ }^{\circ} \mathrm{C}$.

In case of after accumulation, the first degradation step started from 321.47 to $400{ }^{\circ} \mathrm{C}$ with a degradation peak at $371.14^{\circ} \mathrm{C}$ and the second degradation peak was obtained at $564.91{ }^{\circ} \mathrm{C}$ which was started from 437.64 to $650{ }^{\circ} \mathrm{C}$. This states that the adsorbent is thermally stable, and adsorbents (before and after accumulation) show exothermic transition between room temperature and $200{ }^{\circ} \mathrm{C}$ in the air and nitrogen atmosphere, indicating phase change during heating process. The strong exothermic peak was observed at 392.66 and $321.47^{\circ} \mathrm{C}$ in before and after accumulation of heavy metals, respectively; this may be due to combustion of carbon species. In addition, at higher temperature the sample presents a gradual weight loss up to $750{ }^{\circ} \mathrm{C}$. The nature of TG curve gives a clear indication that the two-step degradation is observed for soya waste-based adsorbent.

\section{Effect of pH}

$\mathrm{pH}$ plays a significant role in biosorption of heavy metals; the influence of $\mathrm{pH}$ on the adsorption of $\mathrm{Pb}$ and As by soya bean waste was studied. The $\mathrm{pH}$-dependent adsorption of $\mathrm{Pb}$ and As is shown in Fig. 6, and the optimum adsorption of $\mathrm{Pb}$ and As occurred at $\mathrm{pH} 4.0$ (74.67\%) and $\mathrm{pH} 2.0$ (42.74\%), respectively. Hydrogen ion concentration influences the removal efficiency of metal ions in the aqueous solution and affects the solubility of metal ions in the solution. It also replaces positive ions found on active sites and affects the degree of ionization on the biomass during adsorption. The rate of adsorption was $\mathrm{pH}$ dependent; still the results obtained in this work showed that the rate of $\mathrm{Pb}$ removal did not increase with the increase in the $\mathrm{pH}$ of the aqueous solution. In case of $\mathrm{Pb}$ adsorption, most of active sites were occupied by protons on the biomass surface at lower $\mathrm{pH}$. However, on increasing the $\mathrm{pH}$ from 2.0 to 4.0, soya bean waste biomass surface gets more negatively charged. The

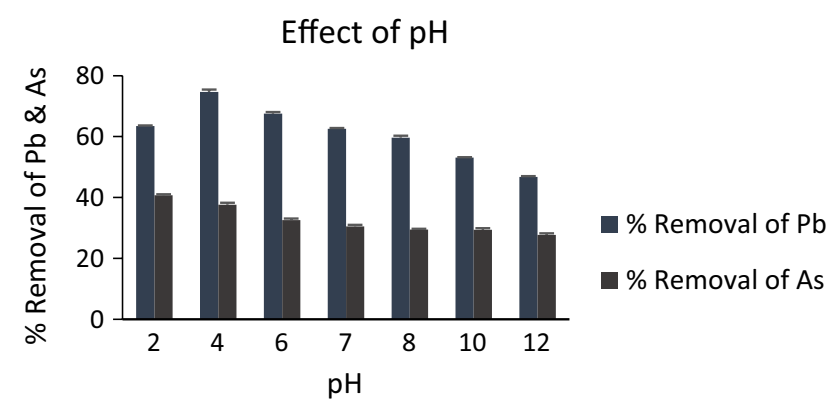

Fig. 6 Effect of $\mathrm{pH}$ on adsorption of $\mathrm{Pb}$ and As. Experimental conditions: temperature $37{ }^{\circ} \mathrm{C}$, contact time $24 \mathrm{~min}$, adsorbent dose $3 \mathrm{~g} / 100 \mathrm{ml}$. Values are mean $\pm \mathrm{SE}, n=3$

positively charges $\mathrm{Pb}$ ion increased and reached at equilibrium on $\mathrm{pH}$ 4.0. At $\mathrm{pH}>4.0$, the concentration of soluble $\mathrm{OH}^{-}$increases which competes with $\mathrm{Pb}$ ions for active sites. These results are in accordance with published data where 4.0 was the optimum $\mathrm{pH}$ for $\mathrm{Pb}$ ions adsorption by microalga (Gagrai and Golder 2010). In present study the optimum $\mathrm{pH}$ for $\mathrm{Pb}$ adsorption was 4.0 and it is almost similar to Spirulina platensis, which has optimum $\mathrm{pH}$ of 3.0 (Al-Homaidan et al. 2016).

Arsenic exists in two forms $\mathrm{As}(\mathrm{III})$ and $\mathrm{As}(\mathrm{V})$, and their distribution is influenced by $\mathrm{pH}$ and redox condition. As(III) is more toxic than $\mathrm{As}(\mathrm{V})$, so there is a need to lower the arsenite level in wastewater. Generally, As(II) and As(V) are the two most abundant forms of arsenic present in environment. Literature survey shows that As(III) gets adsorbed at lower $\mathrm{pH}$ and its level of adsorption decreases with the increase in $\mathrm{pH}$. This may be due to the following reasons. (1) if more numbers of $\mathrm{H}^{+}$ions are present in water solution, then the amount of positive charge over the amino group is more and (2) excessive amount of $\mathrm{H}^{+}$ions present in water competes for active sites of adsorbent. Similar results have been found by Mandal et al., and they performed the 
adsorption studies of As(III) removal from aqueous solution and found highest removal of $\mathrm{As}(\mathrm{III})$ at $\mathrm{pH} \leq 5$ (Mandal et al. 2013). In another study, adsorption studies for As(V) removal were done using activated Moringa oleifera and $\mathrm{pH}$ 7.0 was found to be optimum for As removal (71.3\%). Above $\mathrm{pH} 7.0$, the removal process decreased due to the increase in $\mathrm{H}^{+}$ion concentration which reverses the removal process (Sumathi and Alagumuthu 2014).

\section{Effect of adsorbent dose}

The effect of adsorbent dose was studied at $37{ }^{\circ} \mathrm{C}$ by varying the sorbent amount from 1 to $4 \mathrm{~g} / 100 \mathrm{ml}$. Figure 7 shows the adsorption of $\mathrm{Pb}$ and $\mathrm{As}$ increases with the increase in the amount of soya bean adsorbent up to $4 \mathrm{~g} / 100 \mathrm{ml}$ and later it starts decreasing. The reason may be due to better availability of the surface area as the biosorbent was activated by $\mathrm{NaOH}$. A significant increase in the uptake of $\mathrm{Pb}$ and As was observed when the dose of adsorbent was increased from 1 to $4 \mathrm{~g} / 100 \mathrm{ml}$. Any further increase in the adsorbent dose did not cause any significant change in the adsorption. This may be due to overlapping of adsorption site as a result of overcrowding of adsorbent particles. On the basis of the above results, it can be clearly seen that the metal adsorption on okara can be determined by sorption capacity. The maximum removal of $\mathrm{Pb}$ and As was obtained at the adsorbent dose of $3 \mathrm{~g} / 100 \mathrm{ml}$. Similar trends in terms of optimum adsorbent dose have been reported for the adsorption of Acid Violet 17 dye using $\mathrm{NaOH}$ activated fallen leaves of Ficus racemose (Jain and Gogate 2017). In another study, banana pseudostem was used as an adsorbent for removal of $\mathrm{Pb}$ (II) from aqueous solution and adsorbent dose of $1 \mathrm{~g} / \mathrm{l}$ was found to be optimal dose for the removal of $\mathrm{Pb}$ nitrate (Bagali et al. 2017). Asere et al. reported maximum adsorbent dose for As removal was $8 \mathrm{~g} / \mathrm{l}$ (Asere et al. 2017). Sumathi et al. found that $1.2 \mathrm{~g} / 100 \mathrm{ml}$ of adsorbent dose was optimum for As removal (Sumathi and Alagumuthu 2014).

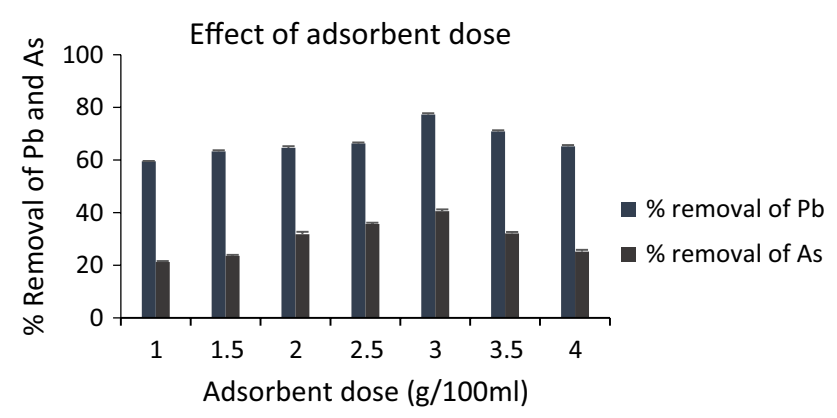

Fig. 7 Effect of adsorbent dose on adsorption of $\mathrm{Pb}$ and As. Experimental conditions: $\mathrm{pH} 4.0(\mathrm{~Pb})$ and 2.0 (As), temperature $37{ }^{\circ} \mathrm{C}$ and contact time $24 \mathrm{~min}$. Values are mean $\pm \mathrm{SE}, n=3$

\section{Effect of contact time}

The effect of contact time was studied at $37{ }^{\circ} \mathrm{C}$ by varying the duration of contact time from 20 to $120 \mathrm{~min}$. For all these runs the adsorbent dose and $\mathrm{pH}$ were fixed as $3 \mathrm{~g} / 100 \mathrm{ml}$ and 4 , respectively. Figure 8 shows that the rate of percent of $\mathrm{Pb}$ and $\mathrm{As}$ removal was higher at the beginning. This was probably due to the larger surface area of the adsorbent being available at the beginning of adsorption process, whereas in later stages, the number of available sites on the biosorbent gets reduced and hence the rate of adsorption was decreased. The maximum percentage removal of $\mathrm{Pb}$ and $\mathrm{As}$ was attained at $60 \mathrm{~min}(1 \mathrm{~h})$ of shaking time. Adsorption of $\mathrm{Pb}$ and $\mathrm{As}$ metals increases with the increase in contact time, but it remained constant after equilibrium was attained. Arimurti et al. did the similar work for $\mathrm{Pb}$ removal by $\mathrm{NaOH}$ activated apple's pomace. They observed that the maximum amount of As was adsorbed at 60 min of incubation time, and later on it decreased with increasing incubation time. These results are in line with present study (Arimurti et al. 2016). In another finding, Jain et al. observed maximum adsorption of As at 60 min of incubation, and later on it started decreasing with the increase in contact time (Jain and Gogate 2017). Similarly, Pokhrel et al. used modified $A$. niger and found that the equilibrium time of As removal was $7 \mathrm{~h}$ (Pokhrel and Viraraghavan 2008). A low-cost adsorbent, activated Moringa oleifera, has been used by Sumathi et al. for As removal from aqueous solution. Their studies showed that 140 min of incubation time was optimum for As adsorption (Sumathi and Alagumuthu 2014).

\section{Effect of temperature}

Effects of temperature on equilibrium sorption capacity of adsorbent for $\mathrm{Pb}$ and $\mathrm{As}$ were investigated at the temperature range of $28-40{ }^{\circ} \mathrm{C}$ at an initial $\mathrm{Pb}$ and As concentration of

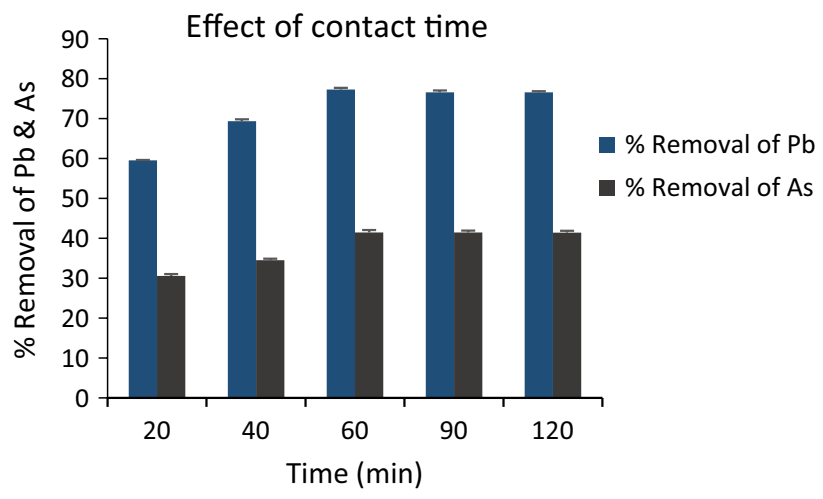

Fig. 8 Effect of contact time on adsorption of $\mathrm{Pb}$ and As. Experimental conditions: adsorbent dose $3 \mathrm{~g} / 100 \mathrm{ml}$, temperature $37^{\circ} \mathrm{C}$ and $\mathrm{pH}$ $4.0(\mathrm{~Pb})$ and $2.0(\mathrm{As})$. Values are mean $\pm \mathrm{SE}, n=3$ 
1.24 and $0.24 \mathrm{mg} / \mathrm{l}$, respectively (Fig. 9). Moreover, temperature directly influences the rate of reaction between biosorbent and biosorbate present in aqueous solution during the adsorption process. The rate of diffusion of the absorbate molecules increases across the external boundary layer and within the pores of adsorbent with the increase in temperature. This could result in decreasing the viscosity of solution. Furthermore, changing the temperature will change the equilibrium capacity of the adsorbent for an individual adsorbate (Khezami and Capart 2005). Hence, this parameter needs to be optimized to get maximum adsorption. A maximum biosorption of $\mathrm{Pb}$ and As was obtained at $37{ }^{\circ} \mathrm{C}$, and it declined with further increase in temperature. The reason may be due to the disruption of equilibrium of ions in solution or destruction of active binding sites in the soya waste biomass or increasing tendency to desorb metal ions from interface of the solution. At higher temperature, the mobility of metal ions increases and it is recommended that the adsorption process is endothermic in nature (Saleem et al. 2007).

Similar results have been observed by Al-Homaidan et al. According to the study, optimum temperature for $\mathrm{Pb}$ adsorption was $26^{\circ} \mathrm{C}$. Beyond this temperature $\left(26^{\circ} \mathrm{C}\right)$, the percent removal of $\mathrm{Pb}$ started decreasing (Al-Homaidan et al. 2016).

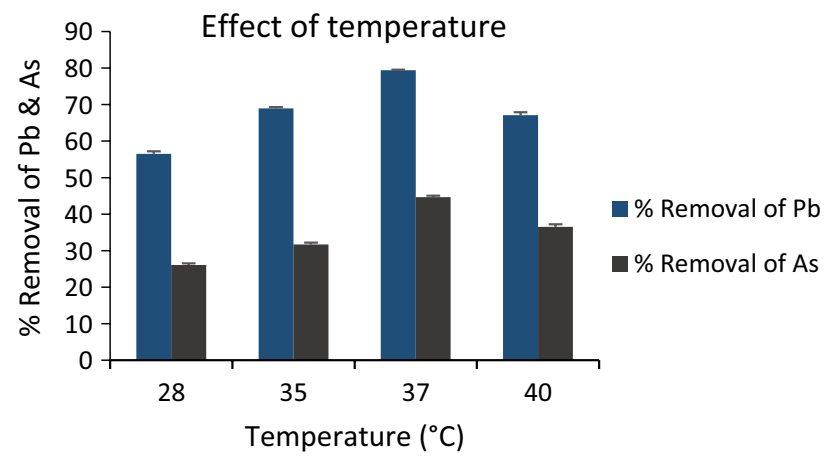

Fig. 9 Effect of temperature on adsorption of $\mathrm{Pb}$ and As. Experimental conditions: adsorbent dose $3 \mathrm{~g} / 100 \mathrm{ml}, \mathrm{pH} 4.0(\mathrm{~Pb})$ and 2.0 (As), contact time $60 \mathrm{~min}$. Values are mean $\pm \mathrm{SE}, n=3$
A few published literature reports that there is no decline in percent removal of $\mathrm{Pb}$ ions from wastewater on increasing the temperature (Erentürk and Malkoç 2007). Mandal et al. studied the effect of different ranges of temperature $\left(20-80{ }^{\circ} \mathrm{C}\right)$ for As removal from industrial wastewater. The literature shows that the highest As removal efficiency was observed at $50{ }^{\circ} \mathrm{C}$ (Mandal et al. 2013).

\section{Adsorption isotherm}

An adsorption isotherm is an expression of the relation between the amount of solute adsorbed and the concentration of the solute in the fluid phase. Since the adsorption isotherms are important to describe how adsorbate will interact with the adsorbent so, it is critically important for the designing of new adsorbents (Hashem 2007).

Langmuir and Freundlich isotherm models were used to study the isotherm studies. The above procedure was repeated except the initial $\mathrm{pH}$ of the solution which was adjusted at the optimum value ( $\mathrm{pH} 2$ for $\mathrm{As}, \mathrm{pH} 7$ for $\mathrm{Pb}$ ) and mass of soya bean adsorbent was $3 \mathrm{~g}$ at different temperatures of $28,35,37$, and $40{ }^{\circ} \mathrm{C}$.

Figure 5 shows the experimental data that were fitted by the linear form of Langmuir model, $C / q_{e}$ versus $C_{e}$, at temperatures of $28,35,37$ and $40{ }^{\circ} \mathrm{C}$. The values of $q_{\max }$ and $b$ were evaluated from the slope and intercept, respectively, for the four isothermal lines. The values of $q_{\max }$ and $b$ are listed in Table 2 with their uncertainty and determination coefficients, $R^{2}$.

Table 2 shows the values of $q_{\max }$ and $b$ (for $\mathrm{Pb}$ and $\mathrm{As}$ ) decreased as the solution's temperature increased from 28 to $40{ }^{\circ} \mathrm{C}$. The decreasing values of $q_{\max }$ and $b$ with increasing temperature indicate that the $\mathrm{Pb}$ and $\mathrm{As}$ ions are favorably adsorbed by soya waste at lower temperatures, which shows that the adsorption process is exothermic.

In order to justify the validity of soya adsorbent biomass as a adsorbent for $\mathrm{Pb}$ and As ions adsorption, its adsorption potential must be compared with other adsorbent like Ficusreligiosa leaves used for this purpose (Qaiser et al. 2009). It may be observed that soya adsorbent showed the
Table 2 Langmuir and Freundlich constants for adsorption of $\mathrm{Pb}$ and $\mathrm{As}$ ions on soya bean adsorbent

\begin{tabular}{|c|c|c|c|c|c|c|c|}
\hline \multirow[t]{2}{*}{ Heavy metals } & \multirow[t]{2}{*}{$T\left({ }^{\circ} \mathrm{C}\right)$} & \multicolumn{3}{|l|}{ Langmuir } & \multicolumn{3}{|c|}{ Freundlich } \\
\hline & & $b$ & $q_{\max }$ & $R^{2}$ & $1 / n$ & $K_{\mathrm{f}}$ & $R^{2}$ \\
\hline \multirow[t]{4}{*}{$\mathrm{Pb}$} & 28 & $0.018 \pm 0.0011$ & $0.72 \pm 0.068$ & 0.96 & 0.256 & $0.176 \pm .002$ & 0.94 \\
\hline & 35 & $0.011 \pm 0.0021$ & $0.66 \pm 0.037$ & 0.85 & 0.05 & $0.531 \pm 0.034$ & 0.88 \\
\hline & 37 & $0.002 \pm 0.0041$ & $0.55 \pm 0.082$ & 0.90 & 0.1 & $0.591 \pm 0.0272$ & 0.95 \\
\hline & 40 & $0.001 \pm 0.0031$ & $0.121 \pm 0.015$ & 0.85 & 0.206 & $0.342 \pm 0.0375$ & 0.90 \\
\hline \multirow[t]{4}{*}{ As } & 28 & $0.0046 \pm 0.0003$ & $0.005 \pm 0.043$ & 0.99 & 1.2 & $0.069 \pm 0.002$ & 0.97 \\
\hline & 35 & $0.0023 \pm 0.0003$ & $0.0047 \pm 0.047$ & 0.98 & 2.01 & $0.707 \pm 0.012$ & 0.99 \\
\hline & 37 & $0.0018 \pm 0.0002$ & $0.084 \pm 0.039$ & 0.82 & 0.4 & $0.763 \pm 0.020$ & 0.89 \\
\hline & 40 & $0.0015 \pm 0.0002$ & $0.019 \pm 0.024$ & 0.99 & 0.6 & $0.698 \pm 0.032$ & 0.95 \\
\hline
\end{tabular}


greater adsorption capacity. The values of $K_{\mathrm{f}}$ and $n$ (for $\mathrm{Pb}$ and As) are listed in Table 2 with their determination coefficients. The experimental data showed that the values of $K_{\mathrm{f}}$ decrease with the increase in temperature of solution from 28 to $40{ }^{\circ} \mathrm{C}$. In addition, this also confirms that the process is also exothermic. The values of $1 / n$ also decreased with increasing temperature.

\section{Forest and agriculture waste as low-cost adsorbent}

In the last few decades, several forest and agriculture waste products have been used as low-cost adsorbent. Agriculture adsorbents such as orange peel, coconut shell, Palmyra palm, peanut hull, rice husk, fly ash, rice husk ash, tea waste, melon peel, pineapple waste have been evaluated for their adsorption properties. Reviews on some forest and agricultural waste used as adsorbents for the removal of $\mathrm{Pb}$ and $\mathrm{As}$ ions from wastewater are presented in Table 3.

\section{Conclusion}

Biosorption is a promising approach for removal of heavy metals. It is not only cost-effective but also shows selectivity and high efficiency toward the removal of heavy metals. Moreover, it does not produce any toxic sludge. These observations postulated for the first time that soya bean adsorbent at the dose of $3 \mathrm{~g} / 100 \mathrm{ml}$ was effective in ameliorating $\mathrm{Pb}$ and As-induced contamination from wastewater. However, better efficacy was shown by the same at optimum temperature $\left(37^{\circ} \mathrm{C}\right), \mathrm{pH}$ ( 4.0 for $\mathrm{Pb}$ and 2.0 for As) and contact time (60 min). Additionally, the isotherm study indicates that the Langmuir and Freundlich isotherm models can adequately model sorption data. As the temperature of the solution increased, the equilibrium removal of metal ions deceased. It was found that the adsorption by soya bean adsorbent is an exothermic process. The thermal degradation analysis suggested that the degradation occurs in two steps and the soya waste is thermally stable.

All the adsorbents mentioned in Table 2 were effective in the removal of $\mathrm{Pb}$ and $\mathrm{As}$ from wastewater. In the current
Table 3 Summary of low-cost adsorbent from forest and agriculture waste

\begin{tabular}{|c|c|c|c|c|}
\hline \multirow[t]{2}{*}{ S. no. } & \multirow[t]{2}{*}{ Adsorbent } & \multicolumn{2}{|c|}{ Metal removal (\%) } & \multirow[t]{2}{*}{ References } \\
\hline & & $\mathrm{Pb}$ & As & \\
\hline \multirow[t]{2}{*}{1} & Rice husk & 87.17 & - & Hegazi (2013) \\
\hline & Fly ash & 76.07 & - & \\
\hline 2 & Melon peel & 72 & - & Gour et al. (2016) \\
\hline 3 & Potato peel and rice husk ash & & 90 & Bibi et al. (2017) \\
\hline \multirow[t]{5}{*}{4} & Chaff & 85 & - & Surchi (2011) \\
\hline & Rice husk & 90 & - & \\
\hline & Sesame husk & 100 & - & \\
\hline & Sun flower husk & 86 & - & \\
\hline & Tea waste & 98 & - & \\
\hline 5 & Egg shell & 97 & - & Arunlertaree et al. (2007) \\
\hline 6 & Coconut nut shell & & & Okafor et al. (2012) \\
\hline 7 & Palm fruit fiber & 73 & - & Ideriah et al. (2012) \\
\hline 8 & Modified orange peel & 20.98 & - & Feng and Guo (2012) \\
\hline 9 & Pineapple waste & 77.16 & - & Mopoung and Kengkhetkit (2016) \\
\hline 10 & Sludge residue & 56.6 & - & Merrikhpour and Jalali (2012) \\
\hline \multirow[t]{10}{*}{11} & Modified corncorbs & 4.34 & - & Mendoza-Castillo et al. (2015) \\
\hline & Fly ash & 1.88 & - & \\
\hline & Natural clays & 2.5 & - & \\
\hline & Carbon obtained from jacaranda fruits & 0.7 & - & \\
\hline & Carbon obtained from plum kernels & 0.54 & - & \\
\hline & Granular activated carbon & & 0.25 & \\
\hline & Powdered eggshell & & 0.19 & \\
\hline & Apricot stone-based activated carbon & & 0.0034 & \\
\hline & $\mathrm{Fe}^{2+}$-loaded activated carbon & & 0.20 & \\
\hline & Iron-modified carbon & & 0.12 & \\
\hline 12 & Peganumharmala seeds & $96-97$ & & Zamani et al. (2013) \\
\hline
\end{tabular}


study, soya waste adsorbent removed $80 \%$ of $\mathrm{Pb}$ and $40 \%$ of As from wastewater. The results are comparable with other mentioned adsorbent in Table 3. Some of the adsorbent are showing more than $95 \%$ removal and $100 \%$ removal as well. These adsorbents were modified with different chemicals to enhance its adsorption capacity. But in the present study adsorbent was used without prior chemical treatment or modification. Therefore, in the future studies its efficiency can be enhanced and evaluated by preparing adsorbent through chemical treatment.

Acknowledgements The author heartily acknowledges Batul Diwan and Gagan Deep Flora of School of Biotechnology, Rajiv Gandhi Proudyogiki Vishwavidyalaya, for their support in execution of experiment. The author is thankful to the Director of Indian Institute of Soil Science for providing the necessary facilities to carry out this study.

\section{Compliance with ethical standards}

Conflict of interest The authors declare that they have no conflict of interest.

Open Access This article is distributed under the terms of the Creative Commons Attribution 4.0 International License (http://creativeco mmons.org/licenses/by/4.0/), which permits unrestricted use, distribution, and reproduction in any medium, provided you give appropriate credit to the original author(s) and the source, provide a link to the Creative Commons license, and indicate if changes were made.

\section{References}

Abou-Mesalam M (2003) Sorption kinetics of copper, zinc, cadmium and nickel ions on synthesized silico-antimonate ion exchanger. Colloids Surf A 225:85-94

Al-Homaidan AA, Al-Abbad AF, Al-Hazzani AA, Al-Ghanayem AA, Alabdullatif JA (2016) Lead removal by Spirulina platensis biomass. Int J Phytoremed 18:184-189

Aneja RK, Chaudhary G, Ahluwalia SS, Goyal D (2010) Biosorption of $\mathrm{Pb}^{2+}$ and $\mathrm{Zn}^{2+}$ by non-living biomass of Spirulina sp. Indian $\mathrm{J}$ Microbiol 50:438-442

Arimurti DD, Heraldy E, Lestari WW (2016) Biosorption of lead(II) ions by $\mathrm{NaOH}$-activated apple (Malus domestica) juice residue. In: AIP conference proceedings, vol 1. AIP Publishing, p 030036

Arunlertaree C, Kaewsomboon W, Kumsopa A, Pokethitiyook P, Panyawathanakit P (2007) Removal of lead from battery manufacturing wastewater by egg shell Songklanakarin. J Sci Technol 29:857-868

Asere TG et al (2017) Removal of arsenic(V) from aqueous solutions using chitosan-red scoria and chitosan-pumice blends. Int J Environ Res Public Health 14(8):895

Bagali SS, Gowrishankar BS, Roy AS (2017) Optimization, kinetics, and equilibrium studies on the removal of lead(II) from an aqueous solution using banana pseudostem as an adsorbent. Engineering 3:409-415. https://doi.org/10.1016/J.ENG.2017.03.024

Bekçi Z, Seki Y, Yurdakoç MK (2007) A study of equilibrium and FTIR, SEM/EDS analysis of trimethoprim adsorption onto K10. J Mol Struct 827:67-74
Bello OS, Adegoke KA, Akinyunni OO (2015) Preparation and characterization of a novel adsorbent from Moringa oleifera leaf. Appl Water Sci 7:1295. https://doi.org/10.1007/s13201-015-0345-4

Bhatnagar A, Sillanpää M, Witek-Krowiak A (2015) Agricultural waste peels as versatile biomass for water purification-a review. Chem Eng J 270:244-271

Bibi S, Farooqi A, Yasmeen A, Kamran MA, Niazi NK (2017) Arsenic and fluoride removal by potato peel and rice husk (PPRH) ash in aqueous environments. Int J Phytoremed 19(11):1029-1036

Carrier M, Loppinet-Serani A, Denux D, Lasnier J-M, HamPichavant F, Cansell F, Aymonier C (2011) Thermogravimetric analysis as a new method to determine the lignocellulosic composition of biomass. Biomass Bioenergy 35:298-307

Dabrowski A (2001) Adsorption-from theory to practice. Adv Coll Interface Sci 93:135-224

Desta MB (2013) Batch sorption experiments: Langmuir and Freundlich isotherm studies for the adsorption of textile metal ions onto teff straw (Eragrostis tef) agricultural waste. J Thermodyn. https://doi.org/10.1155/2013/375830

Dubus IG, Hollis JM, Brown CD (2000) Pesticides in rainfall in Europe. Environ Pollut 110:331-344

Ekmekyapar F, Aslan A, Bayhan Y, Cakici A (2012) Biosorption of $\mathrm{Pb}$ (II) by nonliving lichen biomass of Cladonia rangiformis Hoffm. Int J Environ Res 6:417-424

Erentürk S, Malkoç E (2007) Removal of lead(II) by adsorption onto Viscum album L.: effect of temperature and equilibrium isotherm analyses. Appl Surf Sci 253:4727-4733. https://doi. org/10.1016/j.apsusc.2006.10.042

Fomina M, Gadd GM (2014) Biosorption: current perspectives on concept, definition and application. Bioresour Technol 160:3-14

Gagrai MKDC, Golder AK (2010) Biosorption of heavy metal ions to a microalga Spirulina sp. Annamalai (India). In: Chemical Engineering Congress (CHEMCON)

Gour A, Sharma AK, Sharma S, Verma S (2016) Removal of Lead from aqueous solutions by adsorption on melon peel. IJCS $4: 123-125$

Guo J, Xu W, Ma M (2012) The assembly of metals chelation by thiols and vacuolar compartmentalization conferred increased tolerance to and accumulation of cadmium and arsenic in transgenic Arabidopsis thaliana. J Hazard Mater 199-200:309-313. https://doi. org/10.1016/j.jhazmat.2011.11.008

Hashem MA (2007) Adsorption of lead ions from aqueous solution by okra wastes. Int J Phys Sci 2:178-184

Hegazi HA (2013) Removal of heavy metals from wastewater using agricultural and industrial wastes as adsorbents. HBRC J 9:276282. https://doi.org/10.1016/j.hbrcj.2013.08.004

Ho Y-S, Chiang C-C, Hsu Y-C (2001) Sorption kinetics for dye removal from aqueous solution using activated clay. Sep Sci Technol 36:2473-2488

Ideriah T, David O, Ogbonna D (2012) Removal of heavy metal ions in aqueous solutions using palm fruit fibre as adsorbent. J Environ Chem Ecotoxicol 4:82-90

Jain SN, Gogate PR (2017) Adsorptive removal of acid violet 17 dye from wastewater using biosorbent obtained from $\mathrm{NaOH}$ and $\mathrm{H}_{2} \mathrm{SO}_{4}$ activation of fallen leaves of Ficus racemosa. J Mol Liq 243:132-143. https://doi.org/10.1016/j.molliq.2017.08.009

Jaishankar M, Tseten T, Anbalagan N, Mathew BB, Beeregowda KN (2014) Toxicity, mechanism and health effects of some heavy metals. Interdiscipl Toxicol 7:60-72

Jomova K, Vondrakova D, Lawson M, Valko M (2010) Metals, oxidative stress and neurodegenerative disorders. Mol Cell Biochem 345:91-104

Kharia AA, Singhai AK (2013) Screening of most effective variables for development of gastroretentive mucoadhesive nanoparticles by Taguchi design. ISRN Nanomaterials

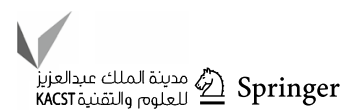


Khezami L, Capart R (2005) Removal of chromium(VI) from aqueous solution by activated carbons: kinetic and equilibrium studies. J Hazard Mater 123:223-231

Li X, Qi J, Jiang R, Li J (2016) Adsorptive removal of As(III) from aqueous solution by waste litchi pericarps. Water Sci Technol 74:2135-2144

Mandal S, Sahu MK, Patel RK (2013) Adsorption studies of arsenic(III) removal from water by zirconium polyacrylamide hybrid material (ZrPACM-43). Water Resour Ind 4:51-67. https ://doi.org/10.1016/j.wri.2013.09.003

Marcano V, Benitez P, Palacios-Prü E (2003) Acyclic hydrocarbon environments $\geqslant \mathrm{n}-\mathrm{C} 18$ on the early terrestrial planets. Planet Space Sci 51:159-166. https://doi.org/10.1016/S0032-0633(02)00203-9

Mendoza-Castillo DI, Rojas-Mayorga CK, García-Martínez IP, PérezCruz MA, Hernández-Montoya V, Bonilla-Petriciolet A, MontesMoran MA (2015) Removal of heavy metals and arsenic from aqueous solution using textile wastes from denim industry. Int $\mathrm{J}$ Environ Sci Technol 12:1657-1668

Merrikhpour H, Jalali M (2012) Waste calcite sludge as an adsorbent for the removal of cadmium, copper, lead, and zinc from aqueous solutions. Clean Technol Environ Policy 14:845-855

Modak J, Natarajan K (1995) Biosorption of metals using nonliving biomass - a review. Miner Metall Process 12:189-196

Mohamad OA, Hao X, Xie P, Hatab S, Lin Y, Wei G (2012) Biosorption of copper(II) from aqueous solution using non-living Mesorhizobium amorphae strain CCNWGS 0123. Microbes Environ 27:234-241

Mopoung R, Kengkhetkit N (2016) Lead and cadmium removal efficiency from aqueous solution by $\mathrm{NaOH}$ treated pineapple waste. Int J Appl Chem 12:23-35

Feng N-C, Guo X-Y (2012) Characterization of adsorptive capacity and mechanisms on adsorption of copper, lead and zinc by modified orange peel. Trans Nonferrous Metals Soc China 22:1224-1231

Okafor P, Okon P, Daniel E, Ebenso E (2012) Adsorption capacity of coconut (Cocos nucifera L.) shell for lead, copper, cadmium and arsenic from aqueous solutions. Int J Electrochem Sci 7:12354-12369

Pennesi C, Vegliò F, Totti C, Romagnoli T, Beolchini F (2012) Nonliving biomass of marine macrophytes as arsenic $(\mathrm{V})$ biosorbents. J Appl Phycol 24:1495-1502. https://doi.org/10.1007/s1081 1-012-9808-2

Pokhrel D, Viraraghavan T (2008) Arsenic removal from an aqueous solution by modified $A$. niger biomass: batch kinetic and isotherm studies. J Hazard Mater 150:818-825. https://doi.org/10.1016/j. jhazmat.2007.05.041

Qaiser S, Saleemi AR, Umar M (2009) Biosorption of lead from aqueous solution by Ficus religiosa leaves: batch and column study. J Hazard Mater 166:998-1005. https://doi.org/10.1016/j.jhazm at.2008.12.003
Saleem M, Pirzada T, Qadeer R (2007) Sorption of acid violet 17 and direct red 80 dyes on cotton fiber from aqueous solutions. Colloids Surf A 292:246-250

Singh N, Gadi R (2012) Bioremediation of $\mathrm{Ni}(\mathrm{II})$ and $\mathrm{Cu}(\mathrm{II})$ from wastewater by the nonliving biomass of Brevundimonas vesicularis. J Environ Chem Ecotoxicol 4:137-142

Srivastava VC, Mall ID, Mishra IM (2006) Characterization of mesoporous rice husk ash (RHA) and adsorption kinetics of metal ions from aqueous solution onto RHA. J Hazard Mater 134:257-267

Su C (2014) A review on heavy metal contamination in the soil worldwide: situation, impact and remediation techniques. Environ Skept Crit 3:24

Sumathi T, Alagumuthu G (2014) Adsorption studies for arsenic removal using activated Moringa oleifera. Int J Chem Eng. https ://doi.org/10.1155/2014/430417

Surchi KMS (2011) Agricultural wastes as low cost adsorbents for $\mathrm{Pb}$ removal: kinetics, equilibrium and thermodynamics. Int J Chem 3(3): 103

Suryan S, Ahluwalia S (2010) Biosorption of heavy metals by paper mill waste from aqueous solution 2(3):1331

Tamás MJ, Sharma SK, Ibstedt S, Jacobson T, Christen P (2014) Heavy metals and metalloids as a cause for protein misfolding and aggregation Biomolecules 4:252-267

Tchounwou PB, Yedjou CG, Patlolla AK, Sutton DJ (2012) Heavy metal toxicity and the environment. In: Luch A (ed) Molecular, clinical and environmental toxicology. Springer, Berlin, pp $133-164$

Vijayaraghavan K, Yun Y-S (2008) Bacterial biosorbents and biosorption. Biotechnol Adv 26:266-291

Vinod V, Sashidhar R (2011) Bioremediation of industrial toxic metals with gum kondagogu (Cochlospermum gossypium): a natural carbohydrate biopolymer. Indian J Biotechnol 10:113-120

Zamani A, Shokri R, Yaftian M, Parizanganeh A (2013) Adsorption of lead, zinc and cadmium ions from contaminated water onto Peganum harmala seeds as biosorbent. Int J Environ Sci Technol 10:93-102

Zhang Y, Liu J (2011) Transgenic alfalfa plants co-expressing glutathione S-transferase (GST) and human CYP2E1 show enhanced resistance to mixed contaminates of heavy metals and organic pollutants. J Hazard Mater 189:357-362

Publisher's Note Springer Nature remains neutral with regard to jurisdictional claims in published maps and institutional affiliations. 